\title{
Tanggung Jawab Negara dan Korporasi Terhadap Kasus Impor Limbah Plastik di Indonesia (Perspektif Konvensi Basel dan Prinsip-Prinsip Panduan Bisnis dan HAM) \\ Muhammad Busyrol Fuad ${ }^{1}$
}

\begin{abstract}
Abstrak
Limbah plastik belakangan ini mendapatkan perhatian yang cukup serius, mengingat tingkat eskalasi masalah ini yang begitu signifikan. Pada 10 Mei 2019, sebanyak 187 negara mengambil satu langkah besar untuk mengendalikan krisis perdagangan plastik dunia dengan memasukkan limbah plastik dalam amandemen Konvensi Basel tentang Pengawasan Perpindahan Lintas Batas Limbah Berbahaya dan Pembuangannya. Selain itu, perpindahan lintas batas limbah plastik dalam skema perdagangan global tersebut melibatkan berbagai kepentingan komersial pada aspek ekspor-impor. Tulisan ini ingin mengaji bagaimana tanggung jawab negara dan korporasi terhadap kasus impor limbah plastik di Indonesia dalam sudut pandang Konvensi Basel dan Prinsip-Prinsip Panduan Bisnis dan Hak Asasi Manusia Perserikatan Bangsa-Bangsa.
\end{abstract}

Kata kunci: Limbah Plastik, Konvensi Basel, Prinsip-Prinsip Panduan Bisnis dan HAM

\section{Abstract}

Plastic waste gets quite serious attention nowadays, considering the problem's level of escalation which was so significant. On May 10, 2019, 187 countries took a major step to improve the global plastic trade by including plastic waste in the amendment of Basel Convention on The Control of Transboundary Movement of Hazardous Waste and Their Disposal. Besides, transboundary movement of plastic waste in the global trade scheme involves various commercial interests in the export-import aspect. This paper will examine state and corporation responsibility in Indonesia's plastic waste import case from Basel Convention on The Control of Transboundary Movement of Hazardous Waste and Their Disposal and United Nation Guiding Principles on Business and Human Rights perspective.

Keyword: Plastic Waste, Basel Convention, UN Guiding Principle on Business and Human Right

\section{Pendahuluan}

Kesenjangan antara permintaan bahan baku dan jumlah bahan baku yang tersedia secara lokal menghendaki adanya perdagangan ekspor-impor antar negara, khususnya bagi negara-negara berkembang atau negara-negara ekonomi transisi. Persoalannya, melalui skema perdagangan global ini, seringkali jenisjenis limbah berbahaya, termasuk dian-

\footnotetext{
${ }^{1}$ Penulis merupakan peneliti di Lembaga Studi dan Advokasi Masyarakat (ELSAM).
} 
taranya limbah plastik "diselundupkan" bersamaan dengan Limbah Non-Bahan Berbahaya dan Beracun berupa kertas yang akan dijadikan bahan baku. ${ }^{2} \mathrm{Di}$ Indonesia misalnya, pada akhir Maret lalu, terdapat 5 (lima) kontainer limbah impor bermasalah dikirim dari Seattle, Amerika Serikat ke Surabaya, Jawa Timur. Bahkan, limbah impor bermasalah tersebut tidak hanya ditemukan di Surabaya, tetapi juga di Batam, Kepulauan Riau, ${ }^{3}$ dan Karawang, Jawa Barat. ${ }^{4}$

Berdasarkan laporan Greenpeace, maraknya kasus limbah impor yang tersebar di beberapa daerah merupakan dampak dari kebijakan Pemerintah China yang melarang importasi hampir semua jenis plastik pada awal tahun 2018. ${ }^{5}$ Akibat dari kebijakan tersebut, negaranegara di Asia Tenggara seperti Indonesia, menerima limpahan sampah plastik yang tercemar dan campuran limbah plastik. ${ }^{6}$ Padahal, limbah plastik itu sulit, bahkan tak mungkin didaur ulang. ${ }^{7}$

Kasus importasi limbah tersebut tidak dapat dianggap ringan, dikarenakan peralihan lintas batas limbah plastik tersebut telah menyebabkan berbagai bentuk pelanggaran yang berdimensi HAM, diantaranya pencemaran, gangguan ter-

\footnotetext{
${ }^{2}$ Dalam kasus Jawa Timur, berdasarkan data Ecological Observation and Wetlands Conservation (ECOTON) tercatat sekitar 12 pabrik kertas di Jawa Timur menggunakan bahan baku kertas impor. Ada 10 negara terbesar pengekspor yaitu Amerika Serikat, Italia, Inggris, Korea Selatan, Australia, Singapura, Yunani, Spanyol, Belanda, dan Selandia Baru. Temuan ECOTON menyebutkan terdapat 35 persen sampah plastik serta sampah rumah tangga lain yang menyusup ke sampah kertas yang dikirim ke Indonesia, tak terkecuali Jawa Timur. Mongabay, Jawa Timur Pastikan Tangani Sampah Impor, https://www.mongabay.co.id/2019/06/29/jawa-timur-pastikan-tangani-masalah-sampah-impor/, diakses pada 8 Agustus 2019.

${ }^{3}$ Kumparan, "Sampah Impor Juga Ditemukan di Batam", https://kumparan.com/@kumparansains/tak-cuma-di-surabaya-kontainer-sampah-impor-juga-ditemukan-di-batam-1rIGYe3DT04, diakses pada tanggal 10 Agustus 2019.

${ }^{4}$ M Ibnu Chazar, "Sampah Impor di Karawang, "https://jabar.antaranews.com/berita/100899/ sampah-impor-di-karawang", diakses pada tanggal 11 Agustus 2019.

${ }_{5}$ Kebijakan pengetatan impor China (Tiongkok) dimulai dengan berlakunya Operation Green Fence pada tahun 2013, dilanjutkan dengan notifikasi ke World Trade Organization (WTO) pada November 2017, hingga secara resmi berlaku dan dikenal dengan National Sword pada Maret 2018. Amy L. Brooks, Shunli Wang, Jenna R. Jambeck, The Chinese Import ban and its impact on global plastic waste trade, http:// advances.sciencemag.org $/$, diakses pada tanggal 9 Agustus 2019.

${ }^{6}$ Greenpeace, Southeast Asia's Struggle Against The Plastic Waste Trade: A Policy Brief For ASEAN Member States, 2019. China merupakan produsen pengolahan sampah daur ulang terbesar di dunia. China sebagai produsen manufaktur menjual produk dalam kemasan ke negara maju. Sebaliknya AS hingga Eropa sebagai importir produk-produk konsumsi mengirim balik sampahnya ke China. Namun, China kemudian menyetop pembelian sampah impor. Kompas, "Konvensi Basel: Perdagangan Sampah Plastik Dikontrol", Kompas Media, Edisi Minggu 12 Mei 2019, hlm. 11 kol. 5-7.

${ }^{7}$ Salah satu sifat plastik adalah membutuhkan waktu lama untuk terdegradasi, atau hampir tidak terdegradasi sama sekali. Dalam air, plastik secara bertahap mendegradasi menjadi partikel yang semakin kecil (mikro dan nano). Partikel-partikel ini yang dapat menarik racun yang pada akhirnya mempengaruhi ekosistem dan berakhir di sistem makanan kita (melalui misalnya, burung dan ikan).
} 
hadap kesehatan hingga kerusakan lingkungan. ${ }^{8}$ Padahal, jaminan hak atas lingkungan hidup yang baik dan sehat sebagai bagian dari HAM telah disematkan dalam Pasal 28 H ayat 1 UUD NRI 1945, yang mengatur "Setiap orang berhak hidup sejahtera lahir dan batin, bertempat tinggal, dan mendapatkan lingkungan hidup yang baik dan sehat serta berhak memperoleh pelayanan kesehatan". Lebih lanjut Pasal 65 ayat (1) UU No. 32 Tahun 2009 tentang Perlindungan dan Pengelolaan Lingkungan Hidup (UU PPLH) juga menegaskan bahwa, "Setiap orang mempunyai hak yang sama atas lingkungan hidup yang baik dan sehat".

Merespons hal tersebut, Conference of the Parties (COP) ke-14 Konvensi Ba$\operatorname{sel}^{9}$ yang diselenggarakan pada $10 \mathrm{Mei}$ 2019, telah sepakat mengambil langkah besar untuk mengamendemen Konvensi Basel $1989 .{ }^{10}$ Setidaknya terdapat dua materi signifikan dalam amendemen ini. Pertama, pengategorian beberapa jenis plastik yang sebelumnya hanya diatur dalam Kode B3010 Lampiran IX ke dalam kategorisasi Lampiran II (limbah lainnya), Lampiran VIII (berbahaya), dengan pengecualian pada Lampiran IX (di luar lingkup konvensi). ${ }^{11}$ Kedua, pemasukan limbah plastik dalam kerangka kerja yang mengikat (legally binding) dan memaksa semua negara pihak untuk menetapkan standar lebih tinggi dalam pengelolaan limbah plastik.

Sayangnya, di samping beberapa pencapaian tersebut, amendemen ini masih meninggalkan titik kritis yang mana pembebanan dalam pencegahan peredaran limbah plastik masih sepenuhnya berada pada negara. Padahal, perpindahan lintas batas limbah plastik dalam skema perdagangan global melibatkan berbagai kepentingan komersial

\footnotetext{
${ }^{8}$ Salah satu dampak kasus impor limbah tersebut tergambar dalam sebuah hasil studi yang menemukan bahwa tingkat Dioksin, PFOS \& Bahan Kimia terlarang lainnya dalam konsentrasi mengkhawatirkan ditemukan pada telur yang diambil dekat lokasi pengolahan sampah plastik di Desa Tropodo, Kecamatan Krian, Kabupaten Sidoarjo, Jawa Timur. Di desa ini, limbah plastik digunakan untuk bahan bakar pabrik tahu. Report, Plastic Waste Poisons Indonesia's Food Chain, IPEN, NEXUS3, ARNIKA, ECOTON, November 2019.

${ }^{9}$ The 14th Conference of the Parties of Basel Convention, Decision No. UNEP/CHW.14/CRP.40; Lihat juga IISD Reporting Services, Earth Negotiations Bulletin, p.18. Selengkapnya tersedia di http:// enb.iisd.org/chemical/cops/2019/, diakses pada tanggal 29 Agustus 2019.

${ }^{10}$ Konvensi Basel atau The Basel Convention on the Control of Transboundary Movement of Hazardous Wastes and Their Disposal, merupakan perjanjian internasional yang mengontrol pergerakan limbah berbahaya beracun dari satu negara ke negara lain, terutama dari negara maju ke negara berkembang. Konvensi ini diadopsi pada tahun 1989 dan mulai berlaku pada tanggal 5 Mei 1992. Konvensi Basel, hal. 5. Berawal dari Proposal Norwegia yang diajukan pada Open-Ended Working Group (OEWG) tertanggal 2 Juni 2018 yang terkandung dalam dokumen UNEP/CHW/OEWG.11/INF36, COP-14 Konvensi Basel memasukkan limbah plastik sebagai objek Konvensi Basel.

${ }^{11}$ Margaretha Quina, dkk. "Kerangka Hukum Perdagangan Limbah Plastik Pengaturan Global dan Nasional", ICEL, Kertas Kebijakan, Juni 2019, Seri Pengelolaan Sampah \#1.
} 
pada aspek ekspor-impor. Dalam iklim kesinambungan rantai pasok (supply (chain) $)^{12}$, sektor bisnis yang terlibat terdiri dari perusahaan produsen (consumer goods), perusahaan pengolahan dan pengelolaan limbah, perusahaan eksportir dan importir limbah, hingga perusahaan pengguna atau produsen kertas.

Seiring dengan menguatnya peran korporasi dalam era globalisasi ekono$\mathrm{mi}$, korporasi juga bertanggung jawab untuk menghormati HAM karena keberadaannya berpotensi melanggar HAM. ${ }^{13}$ Pembebanan tanggung jawab korporasi terhadap HAM ini telah ditegaskan melalui United Nations Guiding Principles on Business and Human Rights atau PrinsipPrinsip Panduan Perserikatan BangsaBangsa tentang Bisnis dan HAM (selanjutnya disebut Prinsip-Prinsip Panduan). Prinsip-Prinsip Panduan ini dibangun dengan tiga pilar utama, yakni kewajiban negara untuk melindungi ${ }^{14}$, tanggung jawab korporasi untuk menghormati ${ }^{15}$, dan akses terhadap pemulihan korban secara efektif ${ }^{16}$.

Upaya menginkorporasikan standar Konvensi Basel 1989 dan Prinsip-Prinsip
Panduan dalam tata kelola perdagangan ekspor-impor limbah plastik merupakan suatu keniscayaan dalam merespons realitas tersebut. Pasalnya, perpindahan lintas batas limbah plastik melalui skema perdagangan limbah global merupakan suatu tantangan mendesak dan serius. Dalam konteks ini, negara perlu menerapkan langkah-langkah campuran cerdas (A Smart Mix Measures) untuk mengantisipasi kasus peredaran limbah plastik melalui skema perdagangan ekspor-impor tidak terjadi lagi.

Selain itu, peran negara sangat diperlukan guna memastikan kepatuhan korporasi terhadap HAM, yaitu dengan turut serta bertanggung jawab menjaga lingkungan bersama dengan pemerintah ataupun masyarakat, mengingat banyaknya kepentingan komersial pada aspek ekspor-impor limbah plastik yang berisiko terhadap HAM, khususnya hak atas lingkungan hidup yang baik dan sehat. Dengan demikian, upaya mendorong korporasi untuk serius dalam menjalankan komitmen mereka dalam mengurangi produk plastik dan beralih ke model bisnis berkelanjutan merupakan hal yang penting.

\footnotetext{
${ }^{12}$ Rantai Pasok meliputi semua pihak yang terlibat, baik langsung maupun tidak langsung dalam pemenuhan permintaan konsumen. Sunil Chopra dan Peter Meindl, Supply Chain Management; Strategy, Planning and Management (New Jersey: Pearson Education Inc., 2007), hlm. 3.

${ }^{13}$ Dampak pelanggaran korporasi terhadap HAM dalam menjalankan aktivitas bisnisnya melingkupi dampak eksternal dan internal. Dampak eksternal berkaitan dengan masyarakat atau komunitas dan lingkungan hidup, sedangkan dampak internal berkaitan dengan aspek ketenagakerjaan.

${ }^{14}$ United Nations Human Right, "Guiding Principles on Business and Human Rights", Prinsip 1 s.d 10.

${ }^{15}$ Ibid., Prinsip 11 s.d 24.

${ }^{16}$ Ibid., Prinsip 25 s.d 31.
} 
Tulisan ini akan melihat bagaimana tanggung jawab negara dan korporasi terhadap permasalahan HAM dalam kasus impor limbah plastik di Indonesia. Prinsip-Prinsip Panduan dan standar yang terdapat dalam Konvensi Basel, diharapkan mampu menjadi pisau analisis yang cukup ampuh mengurai persoalan peredaran limbah plastik.

Tulisan ini akan dibagi menjadi dua bagian untuk menjawab rumusan masalah yang ada. Bagian II akan menjelaskan mengenai relevansi Konvensi Basel dengan Prinsip-Prinsip Panduan. Bagian III akan menganalisis kebijakan pemerintah dalam mengatur perdagangan ekspor-impor limbah serta tanggung jawab korporasi yang terlibat dalam rantai pasok, dengan menggunakan standar yang terdapat dalam Konvensi Basel dan Prinsip-Prinsip Panduan sebagai pisau analisisnya. Di samping itu, bagian ini juga akan menguraikan "a smart mix measures", sebuah istilah yang digunakan dan diyakini sang arsitek Prinsip-Prinsip Panduan, John Ruggie, sebagai langkah kombinasi yang tepat dan bisa digunakan negara dalam membekali realisasi kewajiban negara melindungi HAM sekaligus mendorong peningkatan peng- hormatan HAM oleh korporasi khususnya di sektor ekspor-impor limbah plastik. Terakhir, tulisan ini akan ditutup pada Bagian IV.

\section{Relevansi Konvensi Basel 1989 dengan Prinsip-Prinsip Panduan}

Pada 29 April hingga 10 Mei 2019, United Nations Environment Programme (UNEP) menyelenggarakan pertemuan "Triple COPs" yakni COP Konvensi Basel,$^{17}$ Konvensi Rotterdam, ${ }^{18}$ dan Konvensi Stockholm ${ }^{19}$ yang dihadiri oleh 1.400 perwakilan dari 187 negara di dunia yang digelar di Genewa, Swiss. Pertemuan Triple COPs yang mengambil tema "Clean Planet, Healthy People: Sound Management of Chemicals and Waste" ${ }^{20} \mathrm{ini}$ diinisiasi dalam rangka pembahasan isuisu lingkungan terberat dunia.

Salah satu hasil pertemuan tersebut, melakukan amandemen Konvensi Basel dengan memasukkan limbah plastik sebagai objek Konvensi Basel. Dengan demikian, beberapa jenis limbah plastik, utamanya yang tercampur dan/atau terkontaminasi, akan tunduk pada ketentuan perpindahan lintas batas dalam Konvensi Basel. COP-14 menyepakati perubahan ini berlaku efektif tanggal 1 Januari 2021. ${ }^{21}$

${ }^{17}$ The $14^{\text {th }}$ meeting of the Conference of the Parties (COP-14).

${ }^{18}$ The $9^{\text {th }}$ meeting of the Conference of the Parties (COP-9).

${ }^{19}$ Ibid., (COP-9).

${ }^{20}$ Cherelle Jackson, "Basel COP 14 Promotes Sound Management of Hazardous Wastes", http://sdg. iisd.org/news/basel-cop-14-promotes-sound-management-of-hazardous-wastes/, diakses pada 21 Agustus 2019.

${ }^{21}$ Basel Action Network, "The Norwegian Amandement: Implication for Recyclers", 12 Mei 2019. 
Amandemen Konvensi Basel ini dilakukan seiring dengan maraknya peredaran limbah plastik lintas batas negara yang menyebabkan sejumlah persoalan yang melanggar hak warga negara atas lingkungan hidup yang baik dan sehat seperti pencemaran, gangguan kesehatan dan kerusakan lingkungan. ${ }^{22}$ Hak atas lingkungan hidup yang baik dan sehat tersebut merupakan bagian dari HAM. ${ }^{23}$ Konsekuensinya, Negara sebagai pengemban tugas utama (main duty-bearer) dalam HAM wajib menghormati, memenuhi, dan melindungi hak setiap warga negara atas lingkungan hidup yang baik dan sehat tersebut. ${ }^{24}$

Namun, kewajiban negara dalam konteks ini tentu tidak dapat dijalankan seorang diri tanpa melibatkan peran aktor non-negara yang notabene adalah pihak yang terlibat secara langsung dalam aktivitas peralihan lintas batas limbah plastik dunia, yaitu korporasi. Pada titik ini, pengaturan dimensi tanggung jawab korporasi ini strategis dilakukan untuk memberikan fondasi bagi korporasi dalam mengendalikan berbagai aktivitas yang dapat menyebabkan atau berkontribusi terhadap pencemaran, gangguan kesehatan dan kerusakan lingkungan yang diakibatkan peredaran limbah plastik.

Relasi Bisnis dan HAM merupakan konsekuensi atas perluasan makna organ masyarakat (every organ of society) yang dilekati tanggung jawab HAM. Korporasi sebagai bagian dari organ masyarakat tersebut wajib bertanggung jawab untuk mempromosikan dan menghormati HAM. Langkah pertama yang efektif untuk menjalankan tanggung jawab HAM tersebut dapat dimulai dengan membuka wawasan yang cukup akan relevansi HAM dan bisnis. Korporasi harus sadar bahwa aktivitas industri yang dilakukannya berisiko menimbulkan pelanggaran HAM baik langsung maupun tidak langsung, sehingga peran pencegahan maupun pemulihan haruslah dilaksanakan sebagai bentuk tanggung jawab korporasi dalam perlindungan HAM. ${ }^{25}$

${ }^{22}$ Tingkat keseriusan persoalan tersebut membuat Konferensi Tingkat Tinggi (KTT) G20 yang berlangsung di Osaka, Jepang, selama 28-29 Juni 2019, juga mengangkat permasalahan limbah plastik dalam salah satu bahasannya. Sayangnya permasalahan limbah yang diangkat tidak meliputi permasalahan perdagangan global limbah plastik, namun hanya mencakup permasalahan limbah plastik di laut. "Greenpeace sayangkan KTT G20 tak beri solusi bagi masalah sampah plastik", https://www.aa.com. tr/id/dunia/greenpeace-sayangkan-ktt-g20-tak-beri-solusi-bagi-masalah-sampah-plastik-/1520027, diakses pada tanggal 9 Agustus 2019.

${ }^{23}$ Hal ini sebagaimana disematkan dalam Undang-Undang Dasar Negara Republik Indonesia, Pasal 28 H, Tahun 1945, Pasal 9 ayat (3), Undang-Undang Hak Asasi Manusia No. 39 Tahun 1999, dan UndangUndang Perlindungan dan Pengelolaan Lingkungan Hidup, UU Pasal 65 ayat 1.

${ }^{24}$ Indonesia, Undang-Undang Dasar Negara Republik Indonesia, Tahun 1945 Pasal 28 I Ayat (4) dan (5) dan Pasal 28 J.

${ }^{25}$ Rudi M. Rizki, Tanggung Jawab Korporasi Transnasional dalam Pelanggaran Berat HAM, (Jakarta: Penerbit Fikahati Aneska, 2012), hlm. 17-18. 
Dalam tataran Internasional, John Ruggie, merancang Prinsip-Prinsip Panduan yang kemudian diadopsi Komisi HAM PBB (UNHCR) melalui Resolusi 17/4 pada 16 Juni 2011. Kerangka ini disusun untuk merespons banyaknya pelanggaran HAM yang disebabkan oleh aktivitas korporasi, sehingga dibutuhkan panduan untuk membantu korporasi agar dapat melakukan penghormatan terhadap HAM, terutama dalam menjalankan aktivitas bisnisnya. Instrumen berbentuk panduan ini bersifat soft law $w^{26}$ dan dibangun dengan tiga pilar utama, yakni kewajiban negara untuk melindungi, ${ }^{27}$ tanggung jawab korporasi untuk menghormati, ${ }^{28}$ dan akses terhadap pemulihan korban secara efektif. ${ }^{29}$

Pilar pertama merupakan penegasan bahwa tugas dan kewajiban negara untuk memberikan perlindungan dari pihak ketiga, termasuk korporasi. Melalui kapasitas yang dimilikinya, Prinsip-Prinsip Panduan mensyaratkan negara wajib menetapkan langkah-langkah yang tepat melalui kebijakan, legislasi, regulasi, dan sistem peradilan yang efektif. ${ }^{30}$

Pada pilar kedua Prinsip-Prinsip Panduan mewajibkan korporasi untuk menjalankan aktivitas bisnisnya dengan cara tidak terlibat dengan atau tidak berdampak buruk bagi HAM orang lain, yakni karyawan, masyarakat, konsumen dan lain-lain. ${ }^{31}$ Tanggung jawab ini juga meniscayakan korporasi untuk memahami dengan benar keseluruhan standar dan norma HAM Internasional sebagaimana ditegaskan dalam International Bill of Human Rights, instrumen-instrumen HAM internasional serta instrumen tentang standar dan perlindungan lingkungan hidup yang diterbitkan oleh UNEP, seperti halnya Konvensi Basel.

\footnotetext{
${ }^{26}$ Beberapa sifat dasar dari soft law adalah: a. tidak mengikat dalam arti tidak memiliki kekuatan untuk memaksa penerapannya. Hal ini berbeda dengan instrumen hard law yang memiliki kekuatan untuk memaksa penerapannya melalui ratifikasi kedalam hukum nasional, b. mengandung norma/ prinsip-prinsip umum dan bukan seperangkat aturan (rules), c. soft law adalah instrumen hukum internasional yang tidak mudah dilaksanakan melalui penyelesaian perselisihan yang mengikat. Dengan kata lain, tidak terdapat mekanisme ajudikasi yang jelas untuk menegakkan soft law. Boyle, A. (1999). Some Refelections on the Relationship of Treaties and Soft Law. International and Comparative Law Quarterly, 48 (4), 901-913. Hukum Internasional yang bersifat lunak (soft law) ini memiliki implikasi terhadap substansi hukum internasional karena mengisi kekosongan norma yang ditinggalkan oleh hukum perjanjian internasional. Meskipun bersifat lunak namun memberikan kekuatan normatif karena memberikan interpretasi untuk memperluas dan membatasi perlindungan HAM dalam konteks rezim yang ada. Stéphanie Lagoutte, Thomas Gammeltoft-Hansen, John Cerone, Tracing the Roles of Soft Law in Human Rights, (Oxford: Oxford University Press, Year: 2017), hal. 1.

${ }^{27}$ Prinsip-Prinsip Panduan, Prinsip 1 s.d 10.

${ }^{28}$ Prinsip-Prinsip Panduan, Prinsip 11 s.d 24.

${ }^{29}$ Prinsip-Prinsip Panduan, Prinsip 25 s.d 31.

${ }^{30}$ United Nations Human Right, "Guiding Principles on Business and Human Rights", Prinsip 1 dan Komentarnya.

${ }^{31}$ Ibid., Prinsip 11 dan Komentarnya.
} 
Sementara itu, pilar ketiga PrinsipPrinsip Panduan mengidentifikasi bahwa korporasi telah menyebabkan atau menyumbang dampak yang merugikan, sehingga mereka harus menyediakan pemulihan yang efektif. ${ }^{32}$ Cara-cara yang dapat dilakukan dapat melalui mekanisme negara (yudisial dan non yudisial) atau melalui mekanisme non-negara, atau mekanisme lain yang dipandang tepat untuk memberikan pemulihan yang efektif.

Prinsip-Prinsip Panduan ini memiliki relasi yang erat dengan standar-standar yang termaktub dalam Konvensi Basel. Sebagai instrumen tentang standar dan perlindungan lingkungan hidup yang diterbitkan oleh UNEP, Konvensi Basel membutuhkan instrumen lain ${ }^{33}$ agar standar-standar yang diatur di dalamnya bekerja secara efektif, salah satunya Prinsip-Prinsip Panduan. Keberadaan Prinsip-Prinsip Panduan tersebut mengisi kekosongan peran korporasi dalam Konvensi Basel yang masih sepenuhnya membebankan tanggungjawab pencegahan ataupun pemulihan perma- salahan-permasalahan yang berdimensi HAM sebagai akibat peredaran limbah plastik berada di pundak negara.

Lebih lanjut, dalam tataran kebijakan global, sesungguhnya agenda Sustainable Development Goals (SDGs) 2015-2030 mengenai kesehatan dan lingkungan memiliki posisi strategis dalam menunjang keberhasilan pencapaian pembangunan yang inklusif. Hal ini juga berkorelasi untuk menentukan langkah-langkah konkret dalam mengontrol peredaran limbah plastik dunia. Berkaitan dengan hal tersebut, Executive Secretary pada Sekretariat Konvensi Basel, Katharina Kummer Piery, dalam pengantarnya menyebutkan bahwa segala upaya yang dilakukan untuk memastikan kelestarian lingkungan, seperti meminimalisasi limbah, berpengaruh pada pencapaian SDGs. ${ }^{35}$

Dalam kaitannya dengan pencapaian SDGs tersebut, komunitas korporasi global telah mendeklarasikan dukungan penting atas keberlakuan Prinsip-Prinsip Panduan, sebagaimana ditegaskan sebagai berikut:

\footnotetext{
${ }^{32}$ Ibid.., Prinsip 25 dan Komentarnya.

${ }_{33}$ Selain Konvensi Basel terdapat instrumen Hukum Internasional lainnya yang terkait dengan limbah, diantaranya Montreal Protocol (1987), Minamata Convention (2013), Paris Agreement (2015), UNEP's Global Partnership on Marine Litter, dan G20 Action Plan on Marine Litter. Kemudian terdapat juga Perjanjian Regional: Kuwait Agreement (Persian Gulf and Gulf of Oman, ROPME Sea), Lima Convention (South-East Pasific), Barcelona Convention (Mediterranean Sea), Cartagena Convention (Wider Caribbean).

${ }^{34}$ SDGs terdiri atas 17 tujuan dan 169 sasaran. Resolusi Majelis Umum PBB 70/1, 25 September 2015," Transforming our world: the 2030 Agenda for Sustainable Development."

${ }^{35}$ Konvensi Basel, Pengantar Ms. Katharina Kummer Piery, Executive Secretary, Secretariat of the Basel Convention.
} 
"Kami, organisasi yang bertanda tangan di bawah ini, menegaskan kembali komitmen kami terhadap Prinsip Panduan PBB dan untuk terus mempromosikan implementasinya di antara jaringan bisnis kami (termasuk di tingkat nasional) dan komunitas bisnis global. Kami mendesak perusahaan di mana pun untuk meningkatkan upaya mereka untuk menghormati HAM yang diterima secara universal di seluruh operasi, rantai nilai, dan hubungan bisnis mereka. Memenuhi tanggung jawab perusahaan untuk menghormati HAM adalah kontribusi dan kendaraan utama di mana bisnis dapat membantu mencapai visi yang lebih luas dari masyarakat yang damai dan inklusif yang dianut oleh SDGs. ${ }^{36}$

Dengan demikian, Prinsip-Prinsip Panduan dan Konvensi Basel merupakan instrumen yang saling menguatkan. Selain keberadaan Prinsip-Prinsip Panduan dalam mengisi kekosongan peran korporasi dalam Konvensi Basel, keduanya berupaya dalam mewujudkan tercapainya Tujuan Pembangunan Berkelanjutan. Posisi dominan korporasi dalam aktivitas ekspor-impor limbah plastik, seperti perusahaan produsen (consumer goods), perusahaan pengolahan limbah, perusahaan ekspor/impor, dan perusahaan pengguna bahan-baku, memiliki peran penting dalam penerapan Konvensi Basel. Mereka bahkan berkontribusi untuk mendukung dan memperbaiki tata kelola perdagangan ekspor-impor limbah plastik global yang berwawasan lingkungan. Tanggung jawab korporasi tersebut telah disematkan ke dalam Prinsip-Prinsip Panduan, yang memberikan pembebanan korporasi khususnya yang terlibat dalam perdagangan ekspor-impor limbah untuk menghormati HAM.

\section{Tinjauan Konvensi Basel dan Prinsip-Prinsip Panduan dalam Kasus Impor Limbah Plastik di Indonesia}

\section{A. Kebijakan Pemerintah terhadap Pengaturan Perdagangan Eks- por-Impor Limbah Plastik}

Prinsip-Prinsip Panduan mensyaratkan komitmen negara untuk menangani dampak HAM karena operasional korporasi. Komitmen negara menjadi faktor determinan untuk mengimplementasikan Prinsip-Prinsip Panduan karena adanya persinggungan norma antara hukum internasional dengan hukum nasional. Komitmen negara dalam konteks tata kelola perdagangan eksporimpor limbah telah terwujud dengan diterbitkannya sejumlah regulasi, di antaranya Undang-Undang No. 18 Tahun 2008 tentang Pengelolaan Sampah (UU

\footnotetext{
${ }^{36}$ Lihat Statement in Support of UN Guiding Principles and Sustainable Development Goals, November 2015.
} 
Pengelolaan Sampah), Undang-Undang No. 32 Tahun 2009 tentang Perlindungan dan Pengelolaan Lingkungan Hidup (UU PPLH), Keputusan Presiden No. 61 Tahun 1993 tentang Pengesahan Basel Convention on The Control of Transboundary Movements of Hazardous Wastes and Their Disposal, ${ }^{37}$ berikut amendemennya yang disahkan melalui Peraturan Presiden No. 47 Tahun 2005, dan Peraturan Menteri Perdagangan No. 31/M-DAG/ PER/5/2016 tentang Ketentuan Impor Limbah Non-Bahan Berbahaya dan Beracun (Permendag No. 31 Tahun 2016). ${ }^{38}$

Terkait aktivitas ekspor-impor, pada prinsipnya Undang-Undang No. 7 Ta- hun 2014 tentang Perdagangan mengasumsikan bahwa semua barang dapat diekspor atau diimpor, kecuali yang dilarang, dibatasi, atau ditentukan lain oleh Undang-Undang. Pengecualian tersebut salah satunya termuat dalam ketentuan Pasal 29 ayat (1) UU No. 18 Tahun 2008 tentang Pengelolaan Sampah ${ }^{39}$ dan Pasal 69 ayat (1) UU PPLH. ${ }^{40}$ Berdasarkan ketentuan tersebut, terdapat beberapa hal yang dilarang importasinya, di antaranya sampah dan limbah. Terkait dengan impor limbah, Permendag No. 31/MDAG/PER/5/2016 masih memperbolehkan melakukan impor Limbah Non -B3, hanya saja harus berupa Sisa, Reja, dan Skrap. ${ }^{41}$

\footnotetext{
${ }^{37}$ Walaupun Indonesia bukan negara yang ikut melakukan penandatanganan (signature) teks Konvensi Basel, namun melalui Keputusan Presiden ini, Indonesia melakukan aksesi terhadap konvensi tersebut. Untuk selengkapnya mengenai negara-negara yang menandatangani konvensi ini dan jumlah negara pihak dalam konvensi ini, dapat dilihat di Parties to the Basel Convention on the Control of

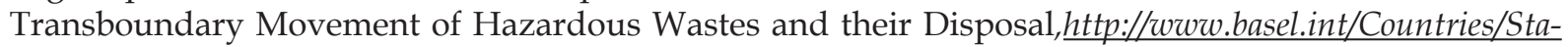
tusofRatifications/PartiesSignatories/tabid/4499/Default.aspx\#enote1, diakses pada tanggal 25 Agustus 2019.

38 Selain itu, sejumlah regulasi lain yang berkaitan dengan pengelolaan limbah dan sampah telah dibuat oleh pemerintah, diantaranya: UU. No. 7 Tahun 1994 tentang Pengesahan Agreement Establishing The World Trade Organization (Persetujuan Pembentukan Organisasi Perdagangan Dunia), UU. No. 10 Tahun 1995 tentang Kepabeanan sebagaimana telah diubah dengan UU. No. 17 Tahun 2006, UU. No. 18 Tahun 2008 tentang Pengelolaan Sampah, UU. No. 39 Tahun 2008 tentang Kementerian Negara, UU. No. 32 Tahun 2009 tentang Perlindungan dan Pengelolaan Lingkungan Hidup, UU. No. 36 Tahun 2009 tentang Kesehatan, UU. No. 3 Tahun 2014 tentang Perindustrian, UU. No. 7 Tahun 2014 tentang Perdagangan, Peraturan Pemerintah No. 101 Tahun 2014 tentang Pengelolaan Limbah Berbahaya dan Beracun dll.

${ }^{39}$ Pasal 29 ayat (1) berbunyi, "Setiap orang dilarang:

a. memasukkan sampah ke dalam wilayah Negara Kesatuan Republik Indonesia;

b. mengimpor Sampah;

c. mencampur sampah dengan limbah berbahaya dan beracun; d. ....dst."

${ }^{40}$ Pasal 69 ayat (1) c menyebutkan: "Memasukkan limbah yang berasal dari luar wilayah Negara Kesatuan Republik Indonesia ke media lingkungan hidup Negara Kesatuan Republik Indonesia".

${ }^{41}$ Pasal 2 ayat (2) Permendag No. 31/M-DAG/PER/5/2016. Terkait kriteria Limbah Non B3 yang dapat diimpor, ketentuan Pasal 4 Permendag No. 31/M-DAG/PER/5/2016 menambahkan bahwa, "Limbah Non B3 dapat diimpor apabila:
}

a. Tidak berasal dari kegiatan landfill atau tidak berupa sampah;

b. Tidak terkontaminasi B3 dan/atau Limbah B3 dan/atau

c. Tidak bercampur dengan limbah lainnya yang tidak diatur dalam Peraturan Menteri ini." 
Terkait dengan sampah, Penulis belum melihat ketegasan aturan tentang "sampah" yang dilarang importasinya berdasarkan UU Pengelolaan Sampah. Definisi yang dijelaskan dalam aturan masih terkesan sangat umum, seperti ketentuan Pasal 1 angka 1 UU Pengelolaan Sampah yang menyebutkan bahwa "Sampah adalah sisa kegiatan sehari-hari manusia dan/atau proses alam yang berbentuk padat". Definisi tersebut tidak membedakan sampah yang ditunjukkan untuk didaur ulang dengan sampah yang ditujukan untuk pembuangan akhir, sebagaimana dapat dilihat dalam pendefinisian "limbah berbahaya" dan "limbah lainnya" dalam Konvensi Basel. Padahal, jika dicermati dalam penjelasan umum UU Pengelolaan Sampah, disebutkan beberapa hal yang menjadi pokok pikiran dibentuknya undang-undang tersebut, salah satunya adalah "kejelasan antara pengertian sampah yang diatur dalam undang-undang dan pengertian limbah sebagaimana diatur dalam Undang-Undang tentang Pengelolaan Lingkungan Hidup".

Kriteria mengenai limbah dan sampah, khususnya yang masih dapat digunakan sebagai bahan baku produk tersebut harus benar-benar jelas. Namun, berdasarkan Kertas Kebijakan yang diterbitkan oleh Indonesian for Center Environmental Law (ICEL) berjudul "Kerangka
Hukum Perdagangan Limbah Plastik: Pengaturan Global dan Nasional" dikatakan bahwa dalam implementasinya, terdapat area abu-abu antara "sampah" dan "limbah" yang masih dapat digunakan sebagai bahan baku produk. ${ }^{42}$

Dalam konteks ini, setelah negara meratifikasi instrumen hukum internasional termasuk juga ikut serta menyepakati amendemennya, negara memiliki kewajiban untuk mengimplementasikan kewajibannya melalui inisiatif-inisiatif reformasi legislatif, termasuk membuat undang-undang yang baru atau amandemen undang-undang yang ada. Regulasi-regulasi yang berkaitan dengan limbah membutuhkan penyesuaian dengan standar yang telah disepakati dalam Konvensi Basel.

Berkaitan dengan hal tersebut, sesungguhnya ketentuan mengenai larangan impor sebagaimana dimaksud dalam Pasal 29 ayat (2) UU Pengelolaan Sampah telah menegaskan bahwa larangan impor sampah ini sesungguhnya didelegasikan untuk diatur lebih lanjut dengan Peraturan Pemerintah (PP). Dalam bagian penjelasan, disebutkan bahwa hal-hal yang diatur dalam PP antara lain adalah jenis, volume, dan/atau karakteristik sampah. Akan tetapi hingga kini, belum ada ketentuan dalam PP yang mengatur lebih lanjut muatan materi dimaksud. ${ }^{43}$

${ }^{42}$ Margaretha Quina, dkk. Op.cit., hal. 5.

${ }^{43}$ Margaretha Quina dan Annisa Erou, "Implementasi Undang-undang Pengelolaan Sampah," dapat diakses di https:/ / icel.or.id/wp-content/uploads/Peraturan-Pelaksana-UU-Pengelolaan-SampahMQ-AE-190221.pdf 
Selain UU Pengelolaan Sampah, yang menjadi dasar hukum dalam mengatur perdagangan ekspor-impor limbah adalah Permendag No. 31 Tahun 2016. Berdasarkan ketentuan Permendag tersebut kasus "penyelundupan" limbah plastik yang terjadi dapat diatasi dengan melakukan re-ekspor atau mengekspor kembali limbah tersebut ke negara eksportir. Pemendag tersebut mengatur apabila Limbah Non-B3 yang diimpor terbukti mengandung Limbah B3, maka importir Limbah Non-B3 wajib melakukan reekspor limbah tersebut paling lama 90 hari, dihitung sejak kedatangan barang berdasarkan dokumen manifes. ${ }^{44}$

Ketentuan waktu reekspor dalam Permendag tersebut bisa dibilang lebih lama dibandingkan dengan waktu reekspor sebagaimana yang diatur dalam Pasal 9 ayat (2) Konvensi Basel, yang mengatur bahwa waktu reekspor adalah 30 hari, dihitung sejak diketahuinya transaksi ilegal. Namun, ada perbedaan antara Permendag No. 31 Tahun 2016 dengan Konvensi Basel. Permendag No. 31 Tahun 2016 membebankan tanggung jawab reekspor sepenuhnya kepada importir, termasuk biaya pelaksanaan reekspor. Sedangkan, ketentuan amandemen Konvensi Basel memberikan dua pilihan ketika impor Limbah Non-B3 terbukti mengandung Limbah B3 atau berasal dari kegiatan landfill dan berupa sampah plastik. Pertama, eksportir atau negara eksportir diharuskan mengambil sendiri limbahnya. Kedua, negara importir mereekspor kepada negara eksportir dan negara eksportir tersebut tidak boleh menolak reekspor. Berpedoman pada kebijakan ini, Pemerintah Indonesia telah melakukan pengembalian 5 kontainer milik PT. Adiprima Suraprinta ke negara asalnya, yaitu Amerika Serikat. ${ }^{45}$

Kasus impor limbah plastik yang terjadi di Indonesia memperlihatkan adanya "kebocoran" pada sistem pengelolaan dan pengawasan perdagangan ekspor-impor limbah. Permendag No. 31 Tahun 2016 telah mengatur upaya preventif selain melalui rezim perizinan, yakni dengan melakukan mekanisme verifikasi dan penelusuran ${ }^{46}$ atau Pre-Shipment Inspection ${ }^{47}$ yang dilakukan oleh $\mathrm{Su}$ -

${ }^{44}$ Indonesia, Menteri Perdagangan, Peraturan Menteri Perdagangan tentang Ketentuan Impor Limbah Non Bahan Berbahaya dan Beracun, Peraturan No. 31 tahun 2016 Pasal 19.

${ }^{45}$ Danu Damarjati, "Indonesia Kirim Balik 5 Kontainer Sampah ke AS", http://m.detik.com/ news/berita/d-4586721/indonesia-kirim-balik-5-kontainer-sampah-ke-AS, diakses pada 30 Agustus 2019

46 Adapun ruang lingkup objek yang dilakukan verifikasi dan penelusuran teknis dapat dilihat dalam Ketentuan Pasal 14 ayat (1) Permendag No. 31 Tahun 2016.

${ }^{47}$ Pre-Shipment Inspection adalah kegiatan inspeksi pra-pengiriman atau pra-pengapalan yang berkaitan dengan verifikasi kualitas, kuantitas, harga, termasuk nilai tukar mata uang dan ketentuan keuangan, dan/atau klasifikasi pabean barang yang akan diekspor ke wilayah anggota pengguna. Lihat WTO Agreement on Pre-Shipment Inspection. 
rveyor. ${ }^{48}$ Ketentuan Permendag mengharuskan surveyor menyusun laporan yang berisi hasil verifikasi dan penelusuran teknis sebagai dokumen pelengkap pabean bidang impor. ${ }^{49}$ Artinya, ketika limbah tersebut tiba di Indonesia, pihak kepabeanan hanya memeriksa berkas/ administratif saja dan tidak mengecek kembali isi kontainer tersebut, dengan alasan sudah dilakukan verifikasi dan penelusuran oleh surveyor.

Di sisi lain, amandemen Konvensi Basel tidak hanya memasukkan limbah plastik sebagai objek dalam konvensi, tetapi juga memberikan penguatan posisi negara dalam aktivitas perdagangan ekspor-impor limbah plastik. Amandemen tersebut mengharuskan negara eksportir mendapatkan persetujuan terinformasi pengiriman (prior informed consent) dari negara penerima sebelum pengiriman limbah, ${ }^{50}$ termasuk informasi dan pernyataan yang tegas mengenai dampak limbah yang dikirim terhadap kesehatan manusia dan lingkungan hidup. ${ }^{51}$ Notifikasi awal sebelum ekspor itu menjadikan amandemen ini sebagai perangkat penting bagi negara-negara di belahan selatan agar menghentikan pembuangan sampah plastik tak diinginkan dari negara-negara maju ke negara-negara berkembang.

Dalam menjalankan kewajibannya untuk melindungi HAM dari dampak negatif aktivitas ilegal perdagangan ekspor-impor limbah plastik, Prinsip-Prinsip Panduan menghendaki negara untuk selalu melakukan evaluasi terhadap regulasi-regulasi yang ada, ${ }^{52}$ khususnya yang mengatur tentang impor limbah. Evaluasi ini juga mengharuskan negara menyesuaikan dengan diskursus internasional yang ada, khususnya mengenai berbagai perjanjian internasional dimana sebuah negara sebagai salah satu negara pihak di dalamnya.

Indonesia sebagai negara pihak Konvensi Basel memiliki kewajiban untuk melakukan langkah reformasi hukum yang diarahkan untuk memperkuat dan menjalani komitmen pemerintah terhadap Hukum HAM Internasional yang telah diratifikasi seperti Konvensi Basel. Berdasarkan doktrin hukum internasional, tindakan ratifikasi tersebut perlu ditindaklanjuti dengan transformasi

\footnotetext{
${ }^{48}$ Pasal 1 angka 10 menyebutkan bahwa Surveyor merupakan perusahaan survey yang mendapatkan otorisasi untuk melakukan verifikasi atau penelusuran teknis impor Limbah Non B3 sesuai dengan ketetapan Kementerian Perindustrian.

${ }^{49}$ Pasal 14 (2). Selain itu Pasal 16 juga menyebutkan dalam melaksanakan kegiatan verifikasi atau penelusuran teknis Impor Limbah Non B3, Surveyor sebagaimana dimaksud dalam Pasal 12 (2) dapat melakukan kerja sama dengan surveyor yang berada di luar negeri.

${ }^{50}$ Konvensi Basel, Op.Cit., Pasal 6 (1).

${ }^{51}$ Konvensi Basel, Op.cit., Pasal 4 (2) (f).

${ }^{52}$ United Nations Human Right, Op.Cit., Prinsip 3 dan Komentarnya.
} 
prinsip dan norma yang ada ke dalam peraturan perundang-undangan yang mengatur tentang perdagangan eksporimpor limbah termasuk dan tidak terbatas pada Permendag No. 31 Tahun 2016, untuk mengefektifkan berlakunya prinsip-prinsip dan norma-norma yang diatur dalam amandemen Konvensi.

Permendag No. 31 Tahun 2016 memiliki beberapa persoalan, termasuk juga menyebabkan masuknya kontainer limbah dari luar negeri yang terkontaminasi dengan Limbah B3. Desakan agar aturan ini direvisi cukup kencang disuarakan, termasuk oleh Kementerian Lingkungan Hidup dan Kehutanan (KLHK). KLHK meminta Kementerian Perdagangan (Kemendag) untuk melakukan revisi atas Permendag No. 31 Tahun 2016 tentang Ketentuan Impor Limbah Non-Bahan Berbahaya dan Beracun. Ada lima usulan setidaknya yang disampaikan Menteri LHK, Siti Nurbaya kepada Kemendag melalui rapat kerja dengan komisi VII DPR RI. Pertama, pada pos tarif (kode HS) impor Limbah Non B3 skrap plastik diusulkan tidak ada kode HS lain-lain sehingga skrap plastik yang diimpor tidak tercampur dengan skrap plastik yang tidak dapat di daur ulang di Indonesia. Kedua, tidak ada penambahan importir baru limbah non B3 skrap plastik. Ketiga, pembatasan kuota impor bagi yang sudah beroperasi sampai lima tahun ke depan. Keempat, mengimpor minimal berupa pellet/chips. Kelima, produk hasil daur ulang harus produk jadi bukan berupa kantong plastik. ${ }^{53}$

Perihal lain mengenai pengalokasian tanggung jawab bagi negara pihak terkait dengan transaksi ilegal juga layak untuk menjadi materi muatan dalam revisi Permendag No. 31 Tahun 2016. Sebagaimana dijelaskan sebelumnya, Permendag hanya langsung membebankan tanggung jawab terhadap importir apabila ditemukan fakta bahwa importasi Limbah Non-B3 terkontaminasi Limbah B3 atau sampah plastik. Dalam ketentuan konvensi Basel telah mengatur mengenai pengalokasian tanggung jawab jika hal tersebut terjadi ${ }^{54}$ sebagai berikut:

a) Tanggung jawab negara pengekspor jika aktivitas ilegal terjadi karena perilaku pengekspor;, 55

b) Tanggung jawab negara pengimpor jika aktivitas ilegal terjadi karena perilaku pengimpor;, 56

Namun persoalannya, walaupun beberapa tanggung jawab ini telah disematkan dalam Konvensi Basel, aspek pelaksanaannya tetap melalui mekanis-

${ }^{53}$ Dewi Purningsih, Polemik Impor Limbah Plastik, KLHK Usulkan Revisi Permendag Nomor 31 Tahun 2016, https://www.greeners.co/berita/polemik-impor-limbah-plastik-klhk-usulkan-revisipermendag-nomor-31-tahun-2016/, diakses pada 29 Agustus 2019

${ }^{54}$ Konvensi Basel, Pasal 9 (1).

${ }^{55}$ Ibid., Pasal 9 (2).

${ }^{56}$ Ibid., Pasal 9 (3). 
me nasional masing-masing negara. Sebagai contoh ketika negara eksportir melakukan aktivitas ilegal akibat perilaku pengekspor sendiri, maka negara pengimpor tidak dapat memaksa dan menuntut pertanggungjawaban tersebut. Salah satu cara yang memungkinkan dilakukan oleh negara pengimpor adalah dengan melakukan protes terhadap negara pengekspor.

\section{B. Tanggung Jawab Korporasi ter- hadap HAM dalam Rantai Pa- sok Limbah Plastik}

Sebagai manifestasi dari tanggung jawab korporasi dalam menghormati HAM, korporasi harus mengetahui dan mampu menunjukkan bahwa mereka mampu menghormati HAM dengan cara, (1) mengadakan komitmen kebijakan yang mendukung tanggung jawab penghormatan HAM, (2) menjalankan uji tuntas HAM secara terus menerus untuk mengidentifikasi, mencegah, mitigasi, dan menghitung dampak HAM, dan (3) memiliki proses-proses yang memungkinkan remediasi bagi dampak yang mengurangi HAM atas aktivitas dan kontribusi bisnis mereka. ${ }^{57}$

Komitmen kebijakan mencerminkan dasar melekatnya tanggung jawab perusahaan menghormati HAM. Perusahaan harus menyatakan komitmen mereka se- cara terbuka, tersedia dan mudah diakses publik. Pernyataan komitmen ini mesti: (1) disetujui pada tingkat yang paling senior dari perusahaan; (2) diinformasikan oleh pakar yang relevan, baik secara internal maupun eksternal; (3) menetapkan ekspektasi hak asasi manusia para personil, rekan bisnis dan pihak lainnya yang secara langsung terkait dengan kegiatan, produk dan layanan perusahaan; dan (4) menjadi bagian dalam kebijakan utama dan prosedur operasional yang melekat bagi seluruh warga perusahaan. ${ }^{58}$

Selain memiliki komitmen kebijakan, korporasi juga perlu menerapkan praktik uji tuntas HAM. Elemen inti dari praktik uji tuntas ini meliputi pernyataan komitmen untuk menghormati hak dan kebijakan pendukung, uji tuntas HAM, termasuk menilai dampak HAM, mengintegrasikan penghormatan terhadap HAM di seluruh fungsi dan proses internal yang relevan, dan melacak serta mengomunikasikan kinerja. ${ }^{59}$

Terakhir, selain komitmen kebijakan dan uji tuntas HAM, korporasi harus memiliki mekanisme keluhan (grievance mechanism). Mekanisme ini memiliki proses yang memungkinkan adanya remediasi (remediation) bagi dampak yang diakibatkan oleh aktivitas perusahaan sehingga menyebabkan berkurangnya penikmatan terhadap HAM.

\footnotetext{
${ }^{57}$ United Nations Human Right, Op.Cit., Prinsip 15 dan Komentarnya.

${ }^{58}$ Ibid., Prinsip 16 dan Komentarnya.

${ }^{59}$ John Ruggie, " the UN "Protect, Respect and Remedy" Framework for Business and Human Rights, 2010.
} 
Dominasi peran korporasi baik swasta maupun Badan Usaha Milik Negara $(B U M N)^{60}$ dalam kasus impor limbah yang terjadi di Indonesia memunculkan dorongan agar korporasi tersebut mengetahui dan mampu menunjukkan bahwa mereka mampu menghormati HAM. Perusahaan swasta merupakan peserta utama dan variabel inti di bidang per- dagangan ekspor-impor limbah plastik, sedangkan BUMN pada sektor ini memainkan peran dalam melakukan PreShipment Inspection. Setidaknya untuk mengetahui peran korporasi yang terlibat dalam perdagangan ekspor-impor limbah plastik tersebut, dapat dilihat melalui siklus rantai pasok dibawah ini:

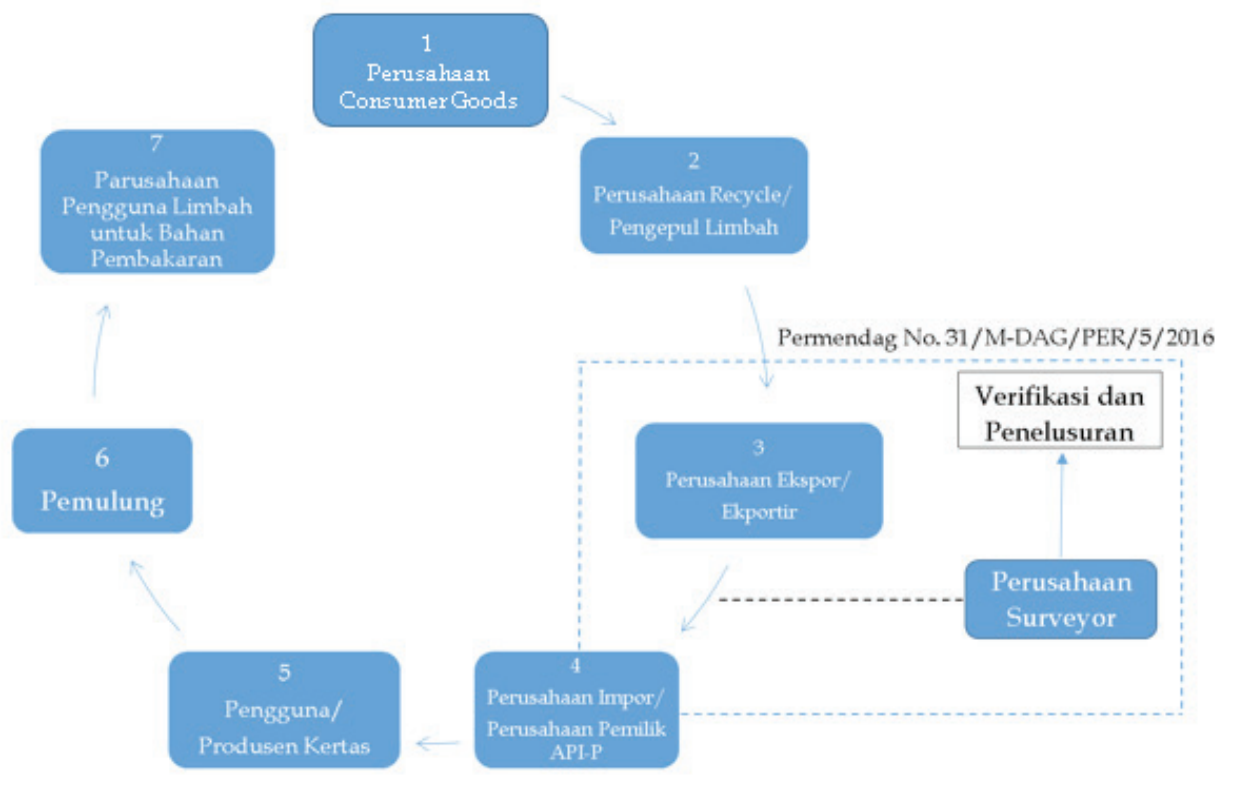

Gambar 4. Rantai Pasok Perdangangan Ekspor-Impor Limbah Plastik

${ }^{60}$ Dalam kerangka Pasal 33 ayat (2) dan (3) UUD 1945, negara dapat mendirikan BUMN yang tunduk pada ketentuan perundang-undangan yang menguasai sistem hukum privat, seperti halnya koperasi dan usaha swasta lainnya. Negara dalam hal ini Pemerintah, hanya sebagai kuasa usaha untuk menyelenggarakan dan/atau mengusahakan cabang-cabang produksi yang penting bagi negara, dan menguasai hajat hidup orang banyak yang meliputi aspek pengaturan, aspek pengendalian dan aspek pengawasan. Lihat Putusan Mahkamah Konstitusi (MK) Nomor 62/PUU-XI/2013. 
Berdasarkan rantai pasok tersebut, terlihat beberapa sektor perusahaan yang terlibat dalam aktivitas ekspor-impor limbah plastik. Dari beberapa jenis perusahaan tersebut, beban tanggung jawab terhadap HAM berbeda-beda. Namun, tulisan ini hanya akan menguraikan beberapa perusahaan terkait dengan porsi tanggung jawabnya.

\section{Perusahaan Produsen Barang Sehari-hari (Consumer Goods) ${ }^{61}$}

Jenis perusahaan ini termasuk perusahaan-perusahaan murah dengan permintaan yang tinggi namun konstan, seperti makanan, minuman, kebersihan pribadi dan produk pembersih rumah tangga ${ }^{62}$ Barang-barang "bergerak ce- pat" ini dibeli secara teratur untuk kebutuhan rumah tangga dan sebagian besar dijual dengan margin rendah dalam volume tinggi, dengan margin laba tipis.

Hasil audit merek oleh gerakan The Break Free from Plastic, termasuk Greenpeace, di tempat limbah kemasan plastik dikumpulkan dan disortir menurut merek, menemukan bahwa Coca-Cola, PepsiCo, Nestlé, Danone, Mondelez International, Procter \& Gamble, Unilever, Perfetti van Melle, Mars Incorporated dan Colgate-Palmolive adalah merek multinasional yang paling sering diidentifikasi, dalam urutan itu. Produk bermerek dari masing-masing perusahaan multinasional ini ditemukan di setidaknya 10 dari 43 negara yang diaudit. ${ }^{63}$

${ }^{61}$ Perusahaan Produsen Barang Sehari-hari atau yang disebut Fast Moving Consumer Goods (FMCG) mewakili salah satu industri terbesar di seluruh dunia, bernilai sekitar \$ 493 Miliar pada tahun 2017. Global Newswire, 2018, Global FMCG Packaging Market Will Reach USD 657.27 Billion by 2024: Zion Market Research, https://globenewswire.com/newsrelease/2018/07/27/1543205/0/en/GlobalFMCG-Packaging-Market-Will-Reach-USD-657-27-Billion-by-2024-Zion-Market-Research.html, diakses pada 28 Agustus 2019.

${ }^{62}$ Ketika perusahaan-perusahaan ini tumbuh dalam paradigma bisnis yang bergantung pada pengemasan plastik saat ini, krisis polusi plastik pasti akan tumbuh secara paralel. Kejenuhan pasar di negara-negara terkaya telah menyebabkan banyak perusahaan multinasional ini, yang sebagian besar berkantor pusat di Amerika Utara dan Eropa, untuk mengejar rencana ekspansi agresif di selatan global; dalam kasus Nestlé, pasar yang sedang berkembang saat ini menyumbang 42 persen dari penjualannya. Jacobs, A. \& Richtel, M. 2017. How Big Business Got Brazil Hooked on Junk Food. The New York Times, 16th September 2017; https:/ / www.nytimes.com/interactive/2017/09/16/health/brazilobesity-nestle.html, diakses pada 29 Agustus 2019. Sedangkan pada komunitas pedesaan merupakan fokus bagi Unilever di Asia Tenggara, di mana pertumbuhan dalam penjualan dihasilkan dari sachet yang mengandung bagian individual dari produk seperti shampoo, pasta gigi, lotion, bumbu, dan makanan siap saji; sachet ini tidak dapat didaur ulang dan membanjiri sistem infrastruktur limbah kota. Posadas, D. 2014. Sachets help low-income communities but are a waste nightmare. The Guardian, 22nd May 2014; https://www.theguardian.com/sustainablebusiness/ sachet-packaging-low-incomecommunities waste-nightmare Horodytska, O, Valdés FJ, Fullana, A, 2018, Plastic flexible films waste management - A state of art review, Waste Management, Volume 77, July 2018, Pages 413-425; https:// wwW.sciencedirect.com/science/article/pii/ S0956053X18302447.

${ }^{63}$ Greenpeace International, "A Crisis of Convenience: The corporations behind the plastic pollution pandemic, A Greenpeace review of the policies, practices and ambitions of significant fast-moving consumer good businesses", hlm. 10. 
Dalam diskursus yang berkembang di negara-negara maju yang tergabung dalam OECD, sedang mendorong pentingnya penerapan doktrin perluasan tanggung jawab produsen (Extended Producers Responsibility/EPR). ${ }^{64}$ Prinsip EPR didefinisikan sebagai:

Prinsip kebijakan yang mendorong sistem penciptaan suatu produk dengan mempertimbangkan aspek lingkungan dari sisi daur hidup produk tersebut dengan cara memperluas tanggung jawab produsen terhadap keseluruhan daur hidup komponen-komponen penyusun produk tersebut, terutama terkait pengambilan kembali (take back), daur ulang dan pembuangan akhir produk.

Dalam konteks hukum nasional, prinsip EPR ini secara substantif diadopsi dalam Pasal 15 UU No. 18 Tahun 2008 tentang Pengelolaan Sampah yang menyatakan bahwa, "Produsen wajib mengelola kemasan dan/atau barang yang diproduksinya yang tidak atau sulit terurai oleh proses alam". Aturan ini lalu dipertegas dalam Pasal 14 PP No. 81 Tahun 2012 tentang Pengelolaan Sampah Rumah Tangga dan Sampah Sejenis Sampah Rumah Tangga. ${ }^{65}$

Sayangnya kebijakan tersebut belum sepenuhnya terealisasi, selain karena kebijakan ini belum mengatur tentang mekanisme sanksi, namun juga mengalami penolakan dari sektor bisnis, khususnya yang tergabung dalam Gabungan Industri Aneka Tenun Plastik Indonesia (GIATPI). ${ }^{66}$ Padahal, di sisi lain PrinsipPrinsip Panduan menekankan bahwa korporasi harus mengambil langkah untuk memastikan plastik sisa produk tidak hanyut ke laut atau tidak diekspor.

\section{Perusahaan Ekspor-Impor Lim- bah}

Dalam konteks perdagangan eksporimpor limbah plastik, tentu perusahaan ekspor, ${ }^{67}$ dan perusahaan API-P atau im-

${ }^{64}$ Istilah Extended Producer Responsibility (EPR) diperkenalkan pertama kali dalam sebuah laporan yang ditujukan kepada Kementerian Lingkungan Hidup Swedia dengan judul "Models for Extended Producer Responsibility. P. Manomaivibool; T. Lindhqvist; N. Tojo, extended producer responsibility in a non OECD contex-the management of waste electrical and electronic equipment in Thailand, IIIEE, Lund University, 2007.

${ }^{65}$ Ketentuan pasal ini berbunyi:

"Produsen wajib melakukan pemanfaatan kembali sampah dengan:

a. Menyusun rencana dan/atau program pemanfaatan kembali sampah sebagai bagian dari usaha dan/atau kegiatannya sesuai dengan kebijakan dan strategi pengelolaan sampah;

b. Menggunakan bahan baku produksi yang dapat diguna ulang; dan/atau

c. Menarik kembali sampah dari produk dan kemasan produk untuk diguna ulang."

${ }^{66}$ Produsen Kemasan Plastik Minta UU Diatur Kembali, http://ditjenpp.kemenkumham.go.id/kilasberita-perkembangan-peraturan-perundang-undangan/1401-produsen-kemasan-plastik-minta-uu-diatur-kembali.html, diakses pada 30 Agustus 2019.

${ }^{67}$ Indonesia, Menteri Perdagangan, Op.Cit., Pasal 1 angka 8, Eksportir Limbah Non B3 adalah perusahaan di negara dimana Limbah Non B3 dihasilkan dan/atau dikapalkan, yang melakukan pengiriman Limbah Non B3 ke Indonesia. 
portir memiliki peran vital dalam menjamin aktivitas importasi Limbah Non B3 agar tidak terkontaminasi Limbah B3 atau sampah plastik. Dengan begitu, pasca amandemen Konvensi Basel, perusahaan yang bergerak di sektor ini harus benar-benar menerapkan standar tinggi dalam pelaksanaan kegiatan eksporimpor limbah.

Seringkali, perusahaan importir juga merupakan perusahaan yang membutuhkan bahan baku, salah satunya adalah perusahaan kertas. Sayangnya, perusahaan kertas tersebut, tidak mampu dalam mengelola kontaminasi plastik yang terkandung dalam limbah kertas. Di Jawa Timur, hasil kajian ECOTON menunjukkan semua pabrik kertas di Daerah Aliran Sungai (DAS) Brantas membuang limbah cair yang mengandung mikroplastik. ${ }^{68}$

Terdapat beberapa langkah yang dapat dilakukan oleh perusahaan ekspor dan impor dalam memastikan aktivitas mereka tidak berdampak HAM, khususnya dampak eksternal yang berkaitan dengan masyarakat dan lingkungan hidup. Pertama, perusahaan importir harus memiliki kualifikasi berdasarkan ketentuan Pasal 3 ayat (1) Permendag No. 31
Tahun 2016. Dengan memenuhi kualifikasi yang terdapat dalam ketentuan tersebut, perusahaan importir dianggap telah melakukan upaya penghormatan HAM dengan cara melakukan mitigasi ataupun upaya preventif terjadinya pelanggaran HAM yang berhubungan dengan operasi, produk atau jasa perusahaan. ${ }^{69}$ Hal tersebut berdasarkan ketentuan Permendag dilakukan dengan cara harus memiliki fasilitas pengelolaan sisa produksi yang menghasilkan buangan yang ramah lingkungan, fasilitas peleburan untuk Limbah Non B3 berupa sisa dan skrap logam, dan fasilitas pengolahan lanjutan untuk Limbah Non B3 selain sisa dan skrap logam.

Kedua, importir harus memiliki komitmen kebijakan terkait HAM misalnya berupa kebijakan yang memastikan bahwa Limbah B3 yang dikirim tidak berasal dari kegiatan landfill atau tidak berupa sampah, dan tidak terkontaminasi B3. Kebijakan tersebut harus disetujui pada level eksekutif tertinggi di perusahaan, yaitu CEO (Chief Executive Officer) dan diturunkan dalam SOP (Standard Operating Procedure). Setelah itu, komitmen kebijakan yang telah dibuat perlu ditindaklanjuti dengan menerapkan me-

${ }^{68}$ Pabrik kertas pengimpor limbah kertas juga tidak mampu mengelola sampah plastik bahkan sebagian memperjualbelikan sampah plastiknya untuk dibakar/bahan bakar industri kecil (pabrik tahu, pabrik krupuk, pembakaran bata). Hanya kurang dari 60\% limbah kertas yang diolah, 30\% low grade material (penyelesaian dengan pembakaran/dibakar secara terbuka) dan 10 \% mengandung limbah B3. Kelalaian ini menyebabkan tercemarnya udara, air sungai, air bawah tanah dan tanah di lokasi penimbunan. Rilis ECOTON, Tolak Impor Sampah Plastik, tanggal 27 Agustus 2019.

${ }^{69}$ United Nations Human Right, Op.Cit., Prinsip Ke-11 dan Komentarnya. 
kanisme uji tuntas HAM agar komitmen kebijakan tersebut mampu terkonfirmasi dalam aras praktik aktivitas perusahaan di lapangan. Ketiga, jika perusahaan menemukan Limbah Non-B3 yang terkontaminasi sampah plastik atau Limbah B3 lainnya dalam aktivitas perdagangan, maka importir bertanggung jawab untuk mengirim kembali limbah tersebut kepada eksportir atau negara eksportir dan menanggung segala biaya pengembalian.

Sedangkan untuk perusahaan eksportir, bentuk tanggungjawab korporasi terhadap HAM tidak jauh berbeda dengan perusahaan lainnya, yakni dengan memiliki komitmen kebijakan dan menerapkan mekanisme uji tuntas HAM. Selain itu berdasarkan ketentuan Pasal 6 ayat (1) Permendag No. 31 Tahun 2016, eksportir harus membuat surat pernyataan yang menerangkan bahwa limbah yang diekspor bukan merupakan Limbah B3 dan eksportir bersedia bertanggung jawab dan menerima kembali Limbah Non B3 yang telah diekspornya apabila Limbah Non B3 tersebut terbukti sebagai Limbah B3. Dengan surat pernyataan tersebut, eksportir berkontribusi dalam mencegah dan memastikan potensi pelanggaran HAM seperti pencemaran dan kerusakan lingkungan tidak terjadi.

\section{Perusahaan Surveyor}

Terhadap setiap pelaksanaan impor Limbah Non-B3 oleh importir wajib dilakukan Verifikasi atau Penelusuran teknis atau Pre-Shipment Inspection di negara muat sebelum dikapalkan. Fungsi ini dilakukan oleh surveyor ${ }^{70}$ yang ditetapkan oleh Menteri dan diatur persyaratannya dalam Permendag No. 31 Tahun 2016. Dalam melakukan fungsinya, surveyor bertanggung jawab atas kebenaran hasil verifikasi ${ }^{71}$ Namun, Permendag No. 31 Tahun 2016 hanya mengatur sanksi bagi surveyor yang lalai menyampaikan laporan verifikasinya setiap bulan kepada Dirjen Perdangangan Luar Negeri Kemendag. ${ }^{72}$ Dengan kata lain, Permendag No. 31 Tahun 2016 tidak mengatur konsekuensi bagi surveyor yang menyampaikan informasi yang tidak benar lebih lanjut.

Di Indonesia, salah satu perusahaan surveyor adalah PT Superintending Company of Indonesia (Persero) atau lebih populer dikenal Sucofindo sebuah perusahaan yang bergerak dalam bidang pemeriksaan, pengawasan, pengujian, dan

${ }^{70}$ Menurut ketentuan Permendag No. 31 Tahun 2016 Pasal 1 angka 10, Surveyor adalah perusahaan survey yang mendapat otorisasi untuk melakukan verifikasi atau penelusuran teknis impor Limbah Non B3.

${ }^{71}$ Ibid., Pasal 14 ayat (4).

${ }^{72}$ Ibid., Pasal 18 jo. Pasal 24. 
pengkajian. ${ }^{73}$ Dalam menjalankan fungsi sebagai surveyor yang bertugas melakukan kegiatan verifikasi dan penelusuran Limbah non-B3, KSO Sucofindo menerbitkan Ketentuan Verifikasi atau Penelusuran Teknis Impor (VPTI) Limbah Non -B3 No. 13/KSO-VPTI/IX/2009.74
Sebagai Badan Usaha Milik Negara (BUMN), Sucofindo memiliki 2 (dua) peran sekaligus, yaitu bertindak untuk kepentingan komersial dan bertindak untuk kepentingan non-komersial $(b a-$ lancing commercial and non-commercial priorities).$^{75}$ Peran Sucofindo untuk meraih

${ }^{73}$ Sebagaimana tercantum dalam anggaran dasar perusahaan, maksud dan tujuan perusahaan (SUCOFINDO) adalah:

a. Melakukan usaha dibidang jasa survey dan inspeksi serta optimalisasi pemanfaatan sumber daya yang dimiliki perseroan untuk menghasilkan barang dan atau jasa yang bermutu tinggi dan berdaya saing kuat untuk mendapatkan dan mengejar keuntungan guna meningkatkan nilai perseroan dengan menerapkan prinsip-prinsip perseroan terbatas.

b. Untuk mencapai maksud dan tujuan tersebut diatas perusahaan dapat melaksanakan kegiatan usaha utama sebagai berikut:

1) Pemeriksaan (inspeksi), pengawasan (supervisi), pengkajian, pemantauan, pengujian, verifikasi yang berkenaan dan berkaitan dengan lapangan usaha Indonesia (KBLI) yang secara umum pada bidang usaha.

2) Survey keadaan barang muatan, sarana dan prasarana angkutan darat, laut dan udara berikut perlengkapannya.

3) Sertifikat, audit, dan assessment yang berkaitan dan berkenaan dengan kegiatan manajemen.

4) Bantuan teknik dan konsultasi yang berkaitan dan berkenaan dengan kegiatan tersebut.

5) Penunjang kegiatan pertambangan, pertanian, perindustrian, perdagangan dan kesehatan. http://www.sucofindo.co.id/tujuan-manfaat-perusahaan.html, diakses pada tanggal 09 Oktober 2019.

${ }^{74}$ Ketentuan tersebut berisi mekanisme aplikasi permintaan verifikasi/inspeksi komoditas Limbah Non B3, meliputi pendaftaran/ pemutakhiran data yang mensyaratkan importir mengirimkan form pemutakhiran data dengan melampirkan dokumen berupa Nomor Pokok Wajib Pajak (NPWP), Tanda Daftar Perusahaan, Izin Usaha Industri (IUI)/Surat Izin usaha Perdagangan (SIUP), Angka Pengenal Impor (API-P) dan Persetujuan Importir (IP) Limbah Non B3, permohonan aplikasi, mekanisme verifikasi penelusuran teknis impor (VPTI) dll.

${ }^{75}$ Apakah BUMN merupakan bagian dari sektor publik atau mirip dengan perusahaan swasta, pertanyaan ini dapat diletakkan pada aturan yang melandasi peran BUMN dalam konteks nasional. Sebagai contoh, di Negara-negara Anggota OECD, bentuk hukum paling umum dari organisasi BUMN adalah sebagai perseroan terbatas (limited liability company). Di samping itu, terdapat kecenderungan lain organisasi BUMN menjadi perusahaan yang dibentuk oleh negara untuk melayani kepentingan publik. Misalnya, Australia dan Inggris, Republik Ceko, Brasil, Indonesia, Rusia, Afrika Selatan, Korea Selatan, Perancis dan, di antara banyak lainnya. Dalam kasus seperti itu, ada kemungkinan bahwa BUMN akan menjadi bagian dari sektor publik. Namun demikian, ada juga kasus ketika BUMN diatur berdasarkan ketentuan hukum privat, sama seperti perusahaan swasta lainnya. Kasus-kasus seperti itu menghadirkan kesulitan tambahan dalam hal klasifikasi karena adakalanya BUMN merupakan bentuk hibrida, yang meluruhkan garis pemisah antara publik dan domain privat. Lihat, Mihaela-Maria Barnes, State-Owned Entities as Key Actors in the Promotion and Implementation of the 2030 Agenda for Sustainable Development: Examples of Good Practices, https://www.mdpi.com/2075-471X/8/2/10/htm\#fn063laws-08-00010, diakses pada 05 Oktober 2019. 
keuntungan dan menjalani kepentingan publik tercantum dalam UU No. 19 Tahun 2003 tentang Badan Usaha Milik Negara. $^{76}$

Dalam kasus "penyelundupan" limbah plastik yang marak terjadi, Sucofindo merupakan salah satu pihak yang dianggap paling bertanggung jawab atas masuknya limbah plastik ke Indonesia. Pasalnya, selaku surveyor, Sucofindo bertanggungjawab dalam melakukan pengecekan terhadap barang impor sebelum masuk ke Indonesia. Bahkan, Sucofindo diduga sebagai pihak yang meloloskan limbah plastik tersebut. ${ }^{77}$

Atas kasus yang terjadi tersebut, sebagai perpanjangan tangan Negara, Sucofindo harusnya juga ikut mengemban tanggung jawab Negara dalam menjamin kepentingan publik salah satunya perlindungan dan penghormatan HAM dengan cara meningkatkan standar kepatuhan HAM yang diharapkan dibandingkan dengan para pelaku korporasi lainnya, melalui instrumen tingkat nasional dan bisnis.

\section{A Smart Mix Measures: Rekaya- sa Cerdas Negara dalam Menga- tur Peredaran Limbah Plastik}

Dalam mengatur peredaran limbah plastik melalui skema perdagangan ekspor-impor yang berisiko terhadap HAM, Indonesia memerlukan kerangka kerja untuk mengimplementasikan komitmen politik HAM dalam memaknai dan menerjemahkan Prinsip-Prinsip Panduan yang mensyaratkan adanya langkahlangkah campuran cerdas "A smart mix of measures" ${ }^{78}$ Istilah tersebut digunakan dan diyakini John Ruggie sebagai lang-

${ }^{76}$ UU No. 19 Tahun 2003 tentang Badan Usaha Milik Negara menyatakan bahwa tujuan dari pendirian BUMN:

1. Memberikan sumbangan bagi perkembangan perekonomian nasional pada umumnya dan penerimaan negara pada khususnya;

2. Mengejar keuntungan;

3. Menyelenggarakan kemanfaatan umum berupa penyediaan barang dan/atau jasa yang bermutu tinggi dan memadai bagi pemenuhan hajat hidup orang banyak,

4. Menjadi perintis kegiatan-kegiatan usaha yang belum dapat dilaksanakan oleh sektor swasta dan koperasi,

5. Turut aktif memberikan bimbingan dan bantuan kepada pengusaha golongan ekonomi lemah, koperasi, dan masyarakat.

${ }^{77}$ Dalam kasus impor limbah plastik di Batam misalnya, Komisi VII DPR RI berencana memanggil Sucofindo dan Surveyor Indonesia dan meminta keterangan terkait lolosnya limbah plastik dari luar negeri masuk Batam. Pemanggilan tersebut dikarenakan keduanya dinilai sebagai pihak yang bertanggungjawab terkait pengecekan barang impor, sebelum dimasukkan ke Indonesia, dalam hal ini Batam. Selain itu, Sucofindo dan Surveyor Indonesia ditengarai sebagai pihak yang meloloskan limbah plastik tersebut.TribunBatam.id, "Disebut Loloskan Sampah ke Batam, DPR RI Bakal Minta Tanggung Jawab Sucofindo dan Surveyor Indonesia," http://batam.tribunnews.com/2019/07/06/disebut-loloskan-sampah-kebatam-dpr-ri-bakal-minta-tanggung-jawab-sucofindo-dan-surveyor-indonesia, diakses pada 10 Oktober 2019.

${ }^{78}$ Shift telah mengembangkan pernyataan tentang peran langkah-langkah rancangan cerdas saat menerapkan Prinsip-Prinsip Panduan, diantaranya: 1). Kewajiban Negara untuk melindungi bukanlah tugas pasif, melainkan tugas proaktif; 2). Kewajiban Negara untuk melindungi dipenuhi melalui kom- 
kah kombinasi yang tepat dan bisa digunakan negara dalam membekali terealisasinya kewajiban negara melindungi HAM sekaligus mendorong peningkatan penghormatan HAM oleh korporasi. ${ }^{79}$

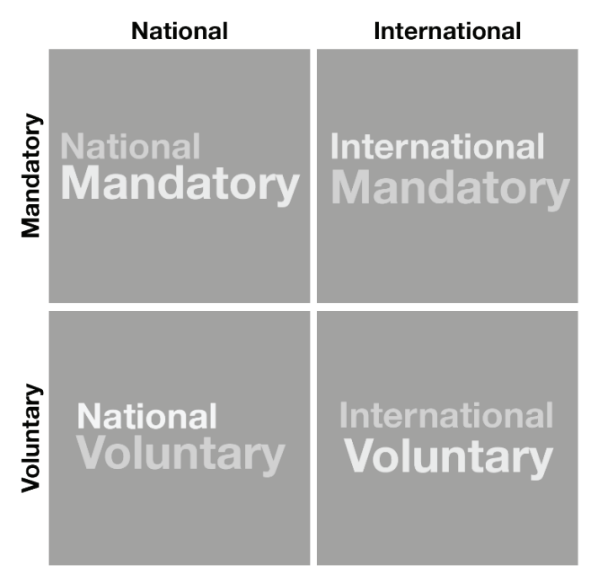

Gambar 5.

\section{Empat Aspek Penting dalam "A Smart Mix Measures" ${ }^{\prime \prime 80}$}

Berdasarkan gambar tersebut, " $a$ smart mix measures" berarti melihat empat aspek, baik nasional, internasional, wajib dan sukarela bukan hanya satu atau dua yang paling nyaman atau yang sudah ada. Oleh karena itu, tugas negara untuk melindungi harus melibatkan langkah-langkah legislatif dan peraturan di tingkat nasional, dan infrastruktur pendukung, seperti penegakan hukum, insentif dan pedoman yang diperlukan untuk menjadikannya bermakna dalam praktik. Tanpa ada upaya untuk menggunakan keempat aspek kebijakan campuran ini, maka Prinsip-Prinsip Panduan tidak akan pernah memenuhi potensi yang sebenarnya. ${ }^{81}$

Dalam konteks maraknya kasus limbah plastik di Indonesia, penerapan " $A$ Smart Mix Measures" sangat relevan untuk diterapkan. Berbagai inisiatif dan pendekatan perlu dilakukan untuk memperkuat peran negara dalam melindungi HAM dalam konteks peredaran limbah plastik. Beberapa inisiatif telah dilakukan oleh negara-negara dalam mengatasi pengurangan limbah plastik, seperti Belanda. Hingga saat ini Belanda belum memiliki regulasi terkait pengurangan limbah plastik, hanya saja Pemerintah Belanda memiliki framework terkait ekonomi sirkular yaitu "A Circular Economy in the Netherland by 2050: Governmentwide Programme for a Circular Economy". Framework ini mengajak aktor industri untuk mengubah desain industri agar

binasi tindakan yang cerdas; 3). Perpaduan cerdas antara tindakan harus melibatkan tindakan legislatif dan peraturan; 4). Langkah-langkah yang melibatkan Uji Tuntas HAM wajib sejalan dengan PrinsipPrinsip Panduan dan terdapat alasan kuat bagi negara untuk mempertimbangkannya. Shift Project, Fulfilling the State Duty to Protect: A statement on the role of mandatory measures in a "smart mix" when implementing the UNGPs,https://www.shiftproject.org/media/resources/docs/shift-stateduty-to-protect.pdf, diakses pada 2 Oktober 2019.

${ }^{79}$ Majda El Muhtaj dalam Abdul Wahid, dkk, Perhutani dan Hak Asasi Manusia: Studi Atas Empat Kasus Penanganan Konflik BUMN Perhutani Ditinjau dari Perspektif Hak Asasi Manusia, (Jakarta: Lembaga Studi dan Advokasi Masyarakat, 2016), hal. xix.

${ }^{80}$ Shift Project, Fulfilling the State Duty to Protect. . . Op Cit.

${ }^{81}$ Ibid. 
selaras dengan prinsip-prinsip sirkular ekonomi, serta penerapan insentifnya. ${ }^{82}$

Penerapan ekonomi sirkular (circular economy) atau ekonomi hijau yang berkelanjutan tersebut agaknya telah menjadi trend internasional saat ini. Sistem ini bertumpu pada tiga prinsip utama yaitu melestarikan dan meningkatkan modal alam, mengoptimalkan hasil sumber daya dan mendorong efektivitas sistem..$^{83}$ Dalam bahasa yang lain, konsep ini merupakan sebuah upaya kolaboratif dengan melibatkan peran setiap pemangku kepentingan dalam setiap tahapan pengelolaan limbah plastik. Dengan menerapkan sistem ekonomi sirkular tersebut, juga berkontribusi dalam mencapai tujuan ke-12 SDGs.

Di Indonesia, penerapan ekonomi sirkular tersebut perlu didorong. Dengan kewenangan yang dimilikinya, pemerin- tah harus terus mendorong perusahaan untuk mengurangi plastik, ${ }^{84}$ misalnya dengan memberikan insentif, atau dengan menerapkan sistem buyback (membeli kembali), yakni perusahaan produsen membeli kembali setiap limbah yang bersumber dari sisa produk brand milik mereka. Setiap botol plastik yang dikembalikan konsumen, akan dapat reward 100 hingga 500 rupiah misalnya.

Langkah pengurangan ini baru satu hal, langkah lain masih diperlukan. Mereka perlu tahu ke mana plastik sisa produk mereka berakhir dan menelan kembali sisa produk mereka. Tentu proses ini akan memakan biaya besar, karena lebih murah memproduksi plastik baru daripada harus mendaur ulang karena akan membutuhkan sumber daya lebih. ${ }^{85} \mathrm{Ne}-$ gara harusnya membuat biaya produksi kemasan plastik baru menjadi mahal, de-

${ }^{82}$ Framework ini disusun dalam merespons penggunaan plastik di Belanda yang telah meningkat dua kali lipat selama 50 (lima puluh) tahun terakhir. Diperkirakan penggunaan plastik akan berlipat ganda sekali lagi dalam dua puluh tahun ke depan. Produksi plastik di seluruh dunia telah meningkat menjadi 299 juta ton pada 2013, sekitar 20 persen di antaranya diproduksi di Eropa. Mayoritas plastik digunakan dalam kemasan. A Circular Economy in the Netherland by 2050: Government-wide Programme for a Circular Economy.

${ }^{83}$ World Economic Forum, The New Plastic Economy Rethinking the future of plastics, Industry Agenda, Januari 2016. h. 17. Usaha daur ulang plastik merupakan salah satu model ekonomi sirkular terhadap limbah plastik. Daur ulang limbah plastik memiliki efek yang signifikan dalam menggerakkan perekonomian masyarakat karena rantai produksinya melibatkan banyak pihak. Dengan demikian, dengan menjadikan sampah plastik sebagai sumber daya.

${ }^{84}$ Beberapa daerah telah menerapkan kebijakan tentang pengurangan sampah. Peraturan Daerah Provinsi Bali No. 5 Tahun 2011 tentang Pengelolaan Sampah menyebutkan dalam Pasal 13 mewajibkan produsen menggunakan bahan baku yang menghasilkan sampah sedikit mungkin atau bisa didaur ulang. Sementara Pasal 14 mewajibkan badan usaha melalukan pemanfaatan dengan menarik sampahnya.

${ }^{85}$ Menurut Direktur ECOTON, Prigi Arisandi, dari sekitar tiga ribu item yang dikumpulkan oleh tim, hampir 55 persen adalah single-use plastic yang berarti sulit didaur ulang. Hal itu yang menjadi alasan negara-negara maju membuang sampah mereka ke luar wilayahnya karena membutuhkan banyak biaya dan sumber daya. https://www.viva.co.id/digital/digilife/1160064-biaya-daur-ulangsampah-plastik-di-indonesia-lebih-murah-dari-as, diakses pada 28 Agustus 2019. 
ngan demikian perusahaan akan beralih ke daur ulang plastik lama.

Dengan cara demikian, perusahaanperusahaan produsen, seperti CocaCola, Unilever, Nestle dapat secara serius mengurangi plastik dan dampak plastik mereka. Apalagi, pada Oktober 2018 perusahaan-perusahaan tersebut menandatangani Komitmen Global Ekonomi Plastik Baru ${ }^{86}$ yang memiliki visi dan target bersama untuk mengatasi limbah plastik dan polusinya. ${ }^{87}$ Selanjutnya dengan menerapkan uji tuntas HAM, dapat dilihat sejauh mana perusahaan-perusahaan tersebut menjalankan komitmen global tersebut.

\section{Penutup}

Amandemen Konvensi Basel telah memasukkan limbah plastik dalam kerangka kerja yang mengikat (legally binding). Kerangka kerja baru ini memaksa semua negara pihak agar menetapkan standar lebih tinggi dalam pengelolaan limbah plastik. Pasalnya kasus "penyelundupan" limbah plastik dalam skema perdagangan ekspor-impor yang terjadi telah berdampak terhadap HAM, khususnya Hak atas Lingkungan Hidup yang Baik dan Sehat. Selain Konvensi Basel, Kewajiban Negara dalam melindungi HAM, juga telah ditegaskan dalam pilar pertama Prinsip-Prinsip Panduan Bisnis dan HAM.

Salah satu bentuk kewajiban Negara terhadap HAM, bahwa Negara harus melaksanakan pengawasan yang memadai dalam rangka memenuhi kewajiban berdasarkan hukum HAM internasional ketika mereka bekerja sama melalui kontrak dengan, atau mengatur, perusahaan untuk menyediakan layanan yang mungkin dapat memiliki dampak pada HAM. Konvensi Basel mensyaratkan keharusan adanya notifikasi awal sebelum ekspor dilakukan atau persetujuan terinformasi pengiriman (prior informed consent), menjadikan amandemen ini sebagai perangkat penting bagi negaranegara di belahan selatan agar menghentikan pembuangan limbah plastik tak diinginkan dari negara-negara maju ke negara-negara berkembang.

\footnotetext{
${ }^{86}$ Komitmen Global adalah komitmen untuk mewujudkan serangkaian target 2025 yang ambisius. Mereka akan bekerja untuk menghilangkan barang plastik yang tidak kita butuhkan; berinovasi sehingga semua plastik yang kita butuhkan dirancang untuk digunakan kembali, didaur ulang, atau dibuat kompos dengan aman; dan beredar semua yang kami gunakan untuk menjaga agar tetap dalam ekonomi dan keluar dari lingkungan. Komitmen global ini diluncurkan oleh Yayasan Ellen MacArthur (EMF) bekerja sama dengan UNEP dan ditandatangani lebih dari 400 anggota yang terdiri dari perusahaan, pemerintah dan LSM. 200 perusahaan yang terlibat dalam komitmen ini merupakan bagian dari rantai nilai kemasan plastik yang digunakan secara global, termasuk perusahaan barang kemasan konsumen terkemuka dunia, pengecer, dan produsen kemasan plastic. New Plastic Report, Global Commitment, UNEP, New Plastic Economy Global Commitment, June 2019 Report.

${ }^{87}$ Ibid.
} 
Selain itu, perpindahan lintas batas limbah plastik dalam skema perdagangan global telah melibatkan berbagai kepentingan komersial pada aspek ekspor-impor, baik swasta maupun BUMN. Pasalnya korporasi merupakan variabel inti di bidang perdagangan ekspor-impor limbah plastik, diantaranya perusahaan produsen (consumer goods), perusahaan pengolahan dan pengelolaan limbah, perusahaan eksportir dan importir limbah, dan perusahaan pengguna atau produsen kertas. Sedangkan BUMN pada sektor ini juga memainkan peran yang tidak kalah penting, yakni melakukan mekanisme verifikasi dan penelusuran teknis atau Pre-Shipment Inspection. Sayangnya, dalam konteks tersebut amandemen Konvensi Basel masih meninggalkan titik kritis dengan tidak memberikan beban pertanggung jawaban korporasi dalam turut serta mencegah peredaran limbah plastik dunia. Dalam konteks inilah, Prinsip-Prinsip Panduan mengisi kekosongan tersebut dengan menekankan adanya pembebanan tanggung korporasi yang terlibat dalam rantai pasok terhadap HAM.

Dengan demikian, korporasi sebagai bagian dari organ masyarakat tersebut wajib bertanggung jawab untuk mempromosikan dan menghormati HAM, termasuk turut serta dalam mengendalikan limbah plastik global. Dengan menerapkan langkah-langkah campuran cer- das (a smart mix measures) melalui penerapan ekonomi sirkular (circular economy) dalam pengelolaan limbah plastik, harapannya permasalahan limbah plastik dapat segera teratasi sehingga juga akan berkontribusi dalam mencapai Tujuan Pembangunan Berkelanjutan (SDGs). 


\section{DAFTAR PUSTAKA}

\section{Peraturan Perundang-Undangan}

Indonesia,Undang-Undang Dasar Negara Republik Indonesia Tahun 1945

,Undang-undang No. 32 Tahun 2009 tentang Perlindungan dan Pengelolaan Lingkungan Hidup (UU PPLH) (LN RI Tahun 2009 Nomor 140, TLN Nomor 5059)

,Undang-undang No. 18 Tahun 2008 tentang Pengelolaan Sampah (LN RI Tahun 2008 Nomor 69)

,Peraturan Pemerintah No. 101 Tahun 2014 tentang Pengelolaan Limbah Berbahaya dan Beracun dll.

Peraturan Presiden RI No. 47 Tahun 2005 tentang Pengesahan Amendment ot the Basel Convention on the Control of Transboundary Movements of Hazardous Wastes and Their Disposal, LN 2005/60.

,Peraturan Menteri Dalam Negeri No. 31/M-DAG/PER/5/2016 tentang Ketentuan Impor Limbah Non Bahan Berbahaya dan Beracun

Peraturan Daerah Provinsi Bali No. 5 Tahun 2011 tentang Pengelolaan Sampah

Keputusan Presiden RI No. 61 Tahun 1993 tentang Pengesahan Basel Convention on the Control of Transboundary Movements of Hazardous Wastes and Their Disposal, LN 1993/62.

Perserikatan Bangsa-Bangsa, United Nations Guiding Principle on Business and Human Rights, diadopsi Komisi HAM
PBB (UNHCR) melalui Resolusi 17/4 pada 16 Juni 2011

, The Basel Convention on the Control of Transboundary Movement of Hazardous Wastes and Their Disposal, diadopsi pada tahun 1989.

Amendment Basel Convention, pada COP-3 Tahun 1995

Amendment Basel Convention, The 14th Conference of the Parties of Basel Convention, Decision No. UNEP/ CHW.14/CRP.40

Proposal Norwegia yang diajukan pada Open-Ended Working Group (OEWG) tertanggal 2 Juni 2018 yang terkandung dalam dokumen UNEP/ CHW/OEWG.11/INF36.

WTO Agreement on Pre-Shipment Inspection

\section{Buku, Artikel, Jurnal}

A Crisis of Convenience: The corporations behind the plastic pollution pandemic, A Greenpeace review of the policies, practices and ambitions of significant fast-moving consumer good businesses.

A, Jacobs \& Richtel, How Big Business Got Brazil Hooked on Junk Food. The New York Times, 16th September 2017; https://www.nytimes.com/interactive/2017/09/16/health/brazil-obesity-nestle.html.

Basel Action Network, “The Norwegian Amendment: Implication for Recyclers", 12 Mei 2019.

Brooks, Amy L., Wang, Shunli, Jambeck, 
Jenna R., The Chinese Import ban and its impact on global plastic waste trade, http://advances.sciencemag.org/.

Global Newswire, Global FMCG Packaging Market Will Reach USD 657.27 Billion by 2024: Zion Market Research, https://globenewswire.com/newsrelease/2018/07/27/1543205/0/en/ Global-FMCG-Packaging-MarketWill-Reach-USD-657-27-Billion-by2024-Zion-Market-Research.html.

Greenpeace, Southeast Asia's Struggle Against The Plastic Waste Trade: A Policy Brief For ASEAN Member States, 2019.

Horodytska, O, Valdés FJ, Fullana, A, Plastic flexible films waste management - A state of art review, Waste Management, Volume 77, July 2018, Pages 413-425; https://www.sciencedirect.com/science/article/pii/ S0956053X18302447.

IISD Reporting Services, Earth Negotiations Bulletin, p.18. Selengkapnya tersedia di http://enb.iisd.org/chemical/cops/2019/.

Jackson, Cherelle, Basel COP 14 Promotes Sound Management of Hazardous Wastes, http://sdg.iisd.org/ news / basel-cop-14-promotessound-management-of-hazardouswastes/.

New Plastic Report, Global Commitment, UNEP, New Plastic Economy Global Commitment, June 2019 Report.

Posadas, D. Sachets help low-income communities but are a waste nightmare. The
Guardian, 22nd May 2014; https:// www.theguardian.com/sustainablebusiness/ sachet-packaging-lowincome-communitieswaste-nightmare

Quina, Margaretha, Erou, Annisa, “Implementasi Undang-undang Pengelolaan Sampah," Februari 2019, dapat diakses di https://icel.or.id/ wp-content/uploads/PeraturanPelaksana-UU-Pengelolaan-SampahMQ-AE-190221.pdf

Quina, Margaretha, Fadhillah, Fajri, Vania, Angela, Kerangka Hukum Perdagangan Limbah Plastik Pengaturan Global dan Nasional, (ICEL, Kertas Kebijakan, Juni 2019, Seri Pengelolaan Sampah\#1).

Rizki, Rudi M, Tanggung Jawab Korporasi Transnasional dalam Pelanggaran Berat HAM, (Jakarta: Penerbit Fikahati Aneska, 2012)

Shift Project, Fulfilling the State Duty to Protect: A statement on the role of mandatory measures in a "smart mix" when implementing the UNGPs,https:// www.shiftproject.org/media/resources/docs/shift-state-duty-to-protect.pdf

Wahid, Abdul, dkk, Perhutani dan Hak Asasi Manusia: Studi Atas Empat Kasus Penanganan Konflik BUMN Perhutani Ditinjau dari Perspektif Hak Asasi Manusia, (Jakarta: Lembaga Studi dan Advokasi Masyarakat, 2016).

World Economic Forum, The New Plastic Economy Rethinking the future of plastics, Industry Agenda, Januari 2016. h. 17 


\section{Media Massa}

Chazar, M. Ibnu, Sampah Impor di Karawang, "https://jabar.antaranews.com/ berita/100899/sampah-impor-di-karawang.

Damarjati, Danu, Indonesia Kirim Balik 5 Kontainer Sampah ke AS, http://m. detik.com/news/berita/d-4586721/ indonesia-kirim-balik-5-kontainersampah-ke-AS.

Ditjenpp Kemenkumham, Produsen Kemasan Plastik Minta UU Diatur Kembali, http://ditjenpp.kemenkumham.go. id/kilas-berita-perkembangan-peraturan-perundang-undangan/1401-produsen-kemasan-plastik-minta-uu-diatur-kembali.html.

Greenpeace sayangkan KTT G20 tak beri solusi bagi masalah sampah plastik", https://www.aa.com.tr/id/dunia/greenpeace-sayangkan-ktt-g20-tak-berisolusi-bagi-masalah-sampah-plastik-/1520027.

Kompas, Konvensi Basel: Perdagangan Sampah Plastik Dikontrol (Kompas Media, Edisi Minggu 12 Mei 2019).

Purningsih, Dewi, Polemik Impor Limbah Plastik, KLHK Usulkan Revisi Permendag Nomor 31 Tahun 2016, https://www.greeners.co/berita/ polemik-impor-limbah-plastik-klhkusulkan-revisi-permendag-nomor31-tahun-2016/.

Rizky Petrus, Jawa Timur Pastikan Tangani Sampah Impor, https://www. mongabay.co.id/2019/06/29/jawatimur-pastikan-tangani-masalahsampah-impor/.
Viva, Biaya Daur Ulang Sampah Plastik di Indonesia Lebih Murah dari AS, https://www.viva.co.id/digital/digilife/1160064-biaya-daur-ulangsampah-plastik-di-indonesia-lebihmurah-dari-as, diakses pada 28 Agustus 2019.

\section{Lain-Lain}

Rilis ECOTON, Tolak Impor Sampah Plastik, tanggal 27 Agustus 2019

Company Profile PT. SUCOFINDO 